\title{
COUNTERACTING INHIBITORY EFFECT OF SALINITY STRESS ON COWPEA GERMINATION USING CYANOBACTERIAL EXTRACTS
}

\author{
Ibrahim Mohamed Zeid, Safia Mohamed Ghazi, Nermin Adel El \\ Semary* and Amira Mohamed Abd El-Sattar
}

\author{
Botany and Microbiology Department, Faculty of Science, Helwan University, \\ Egypt, post code: 11795
}

\begin{abstract}
The response of cowpea seeds grown under salinity-induced stress conditions to different cyanobacterial extracts of two strains (Aphanizomenon flos-aquae and Phormidium sp.) was studied during seed germination. The results indicated that aqueous extract was more stimulating to germination than organic extract where higher levels of germination percentage, enzymatic activity, nucleic acid, protein and total soluble sugars contents were obtained. In addition, the indicators of stress such as proline content, lipid-peroxidation and relative permeability of the root membranes were lower than the organic extract. Application of aqueous cyanobacterial extracts of Aphanizomenon flos-aquae and Phormidium sp. stimulated seed germination and the metabolic activities of salt-stressed and unstressed seeds, while the lipid-peroxidation and relative permeability of the root membranes were reduced. Therefore, aqueous algal extracts alleviated the harmful effect of salinity stress on seed germination. This can be used on a vast scale as an inexpensive and eco-friendly farming policy to counteract the hazardous effect of salinity on plants especially during the critical period of seed germination where salinity can inhibit it either partially or completely.
\end{abstract}

Keywords: Cyanobacteria, germination percentage, enzymatic activity, metabolic activities, lipid-peroxidation, relative permeability

\section{Introduction}

Soil salinity is one of the major abiotic stresses that limits crop productivity worldwide (Hu et al., 2005) as most of the crops are sensitive to soil salinization (Munns 2002). Upon exposure to osmotic stress, plants exhibit a wide range of responses whether at the level of the whole plant or at the cellular level. Morphological and developmental changes in life cycle as well as inhibition of shoot growth and enhancement of root growth constitute whole plant level responses. Cellular and molecular level responses include adjustment in ion transport (such as uptake, extrusion and sequestration of ions) and metabolic 
changes (e.g. carbon metabolism, the synthesis of compatible solutes) which are induced upon regulation of gene expression (Oktem et al., 2006). The direct effects of salt on plant growth may involve (1) a reduction in the osmotic potential of the soil solution that reduces plant-available water, and (2) toxicity of excessive $\mathrm{Na}^{+}$or $\mathrm{Cl}^{-}$towards the plasma membrane. Osmotic effects are associated with inhibition of cell wall extension and cellular expansion, leading to reduced plant growth (Staple and Toenniessen 1984). Clyde et al. (2006) found a significantly high reduction of seeds germination of cowpea due to salinity. The increase in $\mathrm{NaCl}$ concentration was accompanied by more accumulation of sugar and phenol. On contrary, starch level decreased markedly, especially in cotyledons, along with lower amylase activity (Dkhil and Denden 2010).

Cowpea (Vigna sinesis L.) is a summer vegetable legume crop and considered as one of the most important leguminous vegetables crops grown in Egypt as it represents a good source of protein, carbohydrate and other nutrients (Siam 2008). Cowpea is a valuable component of farming systems because as a leguminous plant containing nitrogen-fixing bacterial nodules on its root thereby restoring soil fertility for succeeding cereal crops grown in rotation with it (Sanginga et al., 2003). The nutritional profile of cowpea seed is similar to that of other pulses, with a relatively low fat content and more total protein content. Like other pulses, the protein in cowpea grain is rich in the amino acids lysine and tryptophan, compared to cereal grains. However, it is deficient in methionine and cystine when compared to animal proteins (Timko et al., 2007). El-Jasser (2010) showed that the cowpea and its products contain high level of protein (22.9$77.6 \%)$, high carbohydrates (9.4-64.3\%) and low fats (0.1-0.3\%). Excessive use of chemical fertilizers can have harmful environmental effects. Therefore, crop scientists are exploring alternative sources namely biofertilizers to replace partially or completely chemical fertilizers. These biofertilizers are cost-effective and environment-friendly (Baset and Shamsuddin 2010). Some microorganisms can be considered as bio-fertilizers because of their nitrogen-fixing; phosphate solubilizing and growth-promoting abilities (Goel et al., 1999). For example, several microorganisms have the ability to solubilize phosphorus such as mycorrhizae and Sinorhizobium (Hegde et al., 1999). Among other bio-fertilizers benefiting the crop production are: Azotobacter sp., Azospirillium sp. and cyanobacteria (blue-green algae). Cyanobacteria in particular are regarded as a prolific source of nutrients and bioactive compounds. They are rich sources of vitamins, minerals, essential fatty (including omega 3 fatty acids acids), betacarotene, chlorophyll, phycocyanin, active enzymes, amino acids, proteins, complex sugars, phyto-nutrients, and other components (Kay and Barton 1991). In addition, cyanobacteria have the ability to exude some plant growth hormones including auxins-like substances (Venkataraman 1981). In our study, we used Aphanizomenon flos-aquae (heterocystous unbranched filamentous cyanobacterium) which was reported to contain varying amounts of at least 13 
vitamins: vitamin A (beta-carotene), vitamin $\mathrm{C}$ (ascorbic acid), vitamin $\mathrm{E}$, vitamin $\mathrm{K}$, and many of the B-complex vitamins including B1 (thiamin), B2 (riboflavin), B6 (pyridoxine), choline, biotin, niacin, folic acid, pantothenic acid, and B12 (cobalamin). It also contains minerals and trace minerals including calcium, chloride, chromium, copper, iron, magnesium, manganese, phosphorus, potassium, sodium and zinc). Concomitantly, El Semary (2009) found that this cyanobacteria contains interesting bioactive compounds as well as high content of minerals thereby it can be useful as a foliar spray. Whether or not A. flos-aquae contain a balance of bio-available minerals and trace minerals is dependent on the mineral content of their growth environment. Its protein content is 60\% of its dry weight (Apsley 1995). Another cyanobacteium that is being studied in the present research is the thermophilic filamentous Phormidium sp. This prokaryotic cyanobacterium inhabits some of the Wadi Natroun hypersaline alkaline lakes and was previously reported to be of economic value as a source of biomass for biofuel production (El-Ardy et al., 2012). Extracts from this cyanobacterium were found to influence the overall growth performance and reproductive yield of Vigna mungo, when inoculated with a suitable Bradyrhizobium species (Karthikeyan et al., 2008). There are several reports on nutritional value of Phormidium sp. For example, analyses of Phormidium sp. grown on aeration-stabilized wastewater (ASSW) showed that protein content was $62 \%$ whereas the lipid content was $11 \%$, and the carbohydrates were $16 \%$ of dry weight (Cañizares et al., 1995). The current study is an attempt to investigate the response of cowpea grown under salinity-induced stress conditions to cyanobacterial extracts during the critical stage of seed germination. The study included assaying the effect of cyanobacterial extracts in different solvent systems on the activity of some hydrolytic enzymes and metabolic activities. The permeability of the plasma membrane of the root cells (ion leakage), as well as the lipid-peroxidation are also assayed in order to investigate the ameliorative effect of cyanobacterial extracts on salinity injurious effects.

\section{Materials and Methods}

\section{Cyanobacterial source and growth conditions}

(1) Phormidium sp. was originally isolated from the benthos of a small alkaline (pH 9.5) water body called Lake El Baida, Wade El Natroun, Egypt and kept in Helwan Culture Collection

(2) Aphanizomenon flos-aquae was originally supplied from Bristol Culture collection, The School of Biological Sciences, Faculty of Science, University of Bristol, United Kingdom. Both Phormidium sp. and Aphanizomenon flos-aquae used to establish monospecific cultures in Oscillatoria medium (Feuillade 1994). Aphanizomenon flos-aquae cyanobacterial cultures were maintained at temperature $\left(18 \pm 4{ }^{\circ} \mathrm{C}\right), \mathrm{pH}$ media (6.5-7.5) whereas Phormidium sp. was 
maintained at temperature $\left(30 \pm 5{ }^{\circ} \mathrm{C}\right)$. All cultures were kept at illumination period of $8 / 16$ (light/dark) cycle as Phormidium sp. in particular is very sensitive to long illumination periods.

\section{Cyanobacterial extracts}

Aqueous extraction was performed with distilled water. Biomass was obtained from the cultures after centrifugation and drying of the obtained material followed by diluting it with distilled water into $100 \mathrm{ml}$. In case of preparing cyanobacterial organic extracts, the cyanobacterial biomass was extracted successively using a mixture of different solvents (with different degrees of polarity). The mixture contained equal volumes of chloroform, methanol and distilled water $(1: 1: 1, \mathrm{v}: \mathrm{v}: \mathrm{v})$. The solvent extracts were concentrated using a rotary evaporator under reduced pressure then diluted with distilled water into 100 $\mathrm{ml}$.

\section{Plant materials and growth conditions}

Cowpea seeds (strain Qaha 1) were obtained from the Agriculture Research Center, Giza, Egypt. The seeds were germinated under different osmotic stress values $(0.0,-0.2,-0.4,-0.6,-0.8,-1.0 \mathrm{MPa})$ to determine the lethal concentration. Salinity levels were prepared according to the method described by Zayed and Zeid (1998). Seeds of cowpea were sterilized with $2.5 \%$ sodium hypochlorite solution for three minutes, and thoroughly rinsed three times with distilled water. Equal number ( 25 seeds) of cowpea seeds were transferred to sterile Petri dishes with one filter paper Whatman No. 1, and four replicates were prepared for each treatment. Cyanobacterial extracts of Phormidium sp. and Aphanizomenon flosaquae were applied to seeds with different concentrations of to determine the beneficial and the toxic concentrations on germination. It was found that $0.08 \%$ of Aphanizomenon flos-aquae and $0.01 \%$ of Phormidium sp. gave the best germination at salinity level of $-0.2 \mathrm{MPa}$ concentration of $\mathrm{NaCl}$ and $\mathrm{CaCl}_{2}$ salts so they was chosen as the base for the subsequent experiments. Germination percentage was calculated after 3 days as the number of emerged plumules/ 100 seeds.

\section{Enzymatic activities}

Activity of the hydrolytic enzymes was assayed in the germinating seeds after 3 days from sowing. The cell-free extract of the plant material was prepared at $0-4{ }^{\circ} \mathrm{C}$ by macerating the seeds with a chilled pestle and mortar. The tissue homogenate was centrifuged at $10,000 \mathrm{~g}$ for $20 \mathrm{~min}$ and the supernatant obtained was used directly for determining enzyme activity. For $\alpha$ - and $\beta$-amylases, 3, 5dinitrosalicylic acid reagent was used according to Bergmeyer (1974). Protease activity was assayed according to the method described by Bergmeyer (1974). 
Activity of ribonuclease was assayed by the method described by Malik and Singh (1984).

\section{Chemical analyses}

Fresh seedlings were extracted in $70 \%$ ethanol and completed to a known volume with distilled water and used for estimation of total soluble sugars using anthrone reagent (Umbriet $\boldsymbol{e t}$ al., 1959) and the total soluble proteins by the procedure of Lowry et al., (1951). Total carbohydrates content was estimated after carrying out hydrolysis of the dry plant matter in $10 \mathrm{ml}$ of $1 \mathrm{~N}_{2} \mathrm{SO}_{4}$, and measured as total soluble sugars using anthrone reagent (Umbriet $\boldsymbol{e t}$ al., 1959). DNA and RNA were extracted by the method of Marmur (1961) and estimated by the method of Dische and Schwartz (1973). Proline was determined according to (Bates et al., 1973). Fresh root segments were used for measuring of lipid-peroxidation, by the thiobarbituric acid (TBA) colour reaction according to (Bernheim et al., 1948). The relative permeability of the root membranes was calculated as described by (Zwiazek and Blake 1991).

\section{Statistical analysis}

Statistical analysis was carried out according to Snedecor and Cochran (1980) using analysis of variance and the significance was determined using LSD values at $\mathrm{P}=0.05$ and 0.01 .

\section{Results}

The values of germination percentage were always greater in the control than under different salinity concentrations (Fig. 1). Germination percentage declined with increasing salinity concentration from -0.2 to $-1.0 \mathrm{MPa}$ of cowpea to reach minimal value at (-1.0) MPa. The values of germination were reduced by different concentration of organic and aqueous extracts of cyanobacterial Aphanizomenon $s p$ treatment at salt-induced stress and unstressed conditions except at concentration $0.08 \%$ of aqueous extract which gave the highest values of germination of salt-stressed and unstressed seeds. At this aqueous extract level, there was a notable increase in germination percentage of unstressed seeds from 84 to $90 \%$, while under salinity stress the values increased from 73 to $84 \%$. However the other concentration 0.04 and $0.16 \%$ also reduced germination percentage of stressed and unstressed seeds (Table 2) 


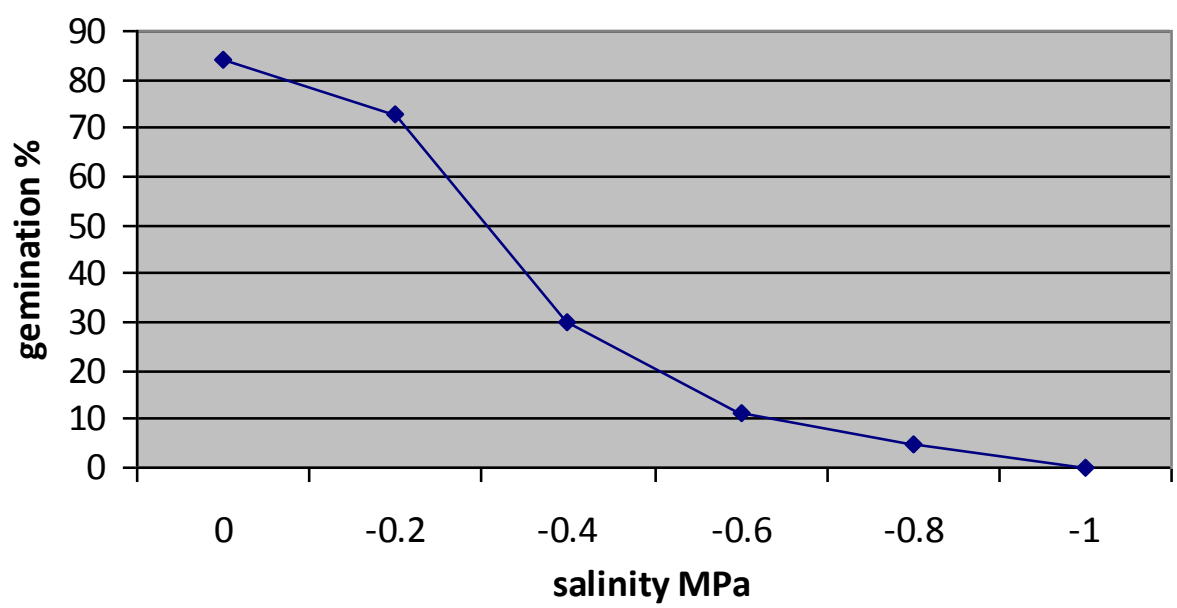

Figure 1: Effect of different osmotic stress values on germination percentage of cowpea seeds (3-d-old).

This concentration of algal suspension gave highest germination percentage as compared to control and salinity. Treatment with extract of cyanobacterial Phormidium sp. also reduced the germination percentage of unstressed seeds at all concentrations of aqueous and organic extracts but under salinity stress the value of germination was increased by $9 \%$ at concentration $0.01 \%$ of aqueous extract and by $7 \%$ at organic extract (Table 2 ).

Germination percentage of cowpea seeds was negatively affected by the different treatments except with aqueous Aphanizomenon extract that increased the value of germination of unstressed seeds. On the other hand, under salinity stress the highest value of germination was obtained with seeds treated with aqueous extract of Aphanizomenon followed by aqueous Phormidium extract and their mixture, organic extract with two different species also increased germination percentage but it was reduced in case of their mixture (Table 3). It was observed that the values of germination at organic extract of different species were always lower than the values of aqueous extract of different species. Data represented in (Table 3) indicate that the total soluble proteins content showed significant differences under salinity stress and different cyanobacterial treatments. In case of unstressed seeds the highest value was obtained in seeds treated with aqueous extract of Aphanizomenon which resulted in an increase in total soluble proteins content from 9.61 to 11.65 followed by the combination between the two extracts. 
Table 2: Effect of different concentrations of two cyanobacterial extracts of Aphanizomenon sp. and Phormidium sp. on the germination of cowpea seeds in the control and salinity-induced stress conditions (3-d-old).

\begin{tabular}{|c|c|c|c|c|}
\hline \multicolumn{3}{|c|}{ Treatments } & \multirow{2}{*}{$\begin{array}{l}\text { Germination\% } \\
\text { of aqueous extract } \\
\text { (Solvent: water) }\end{array}$} & \multirow{2}{*}{$\begin{array}{c}\text { Germination\% } \\
\text { of organic extract } \\
\text { (Solvent: chloroform } \\
\text { methnol: water) }\end{array}$} \\
\hline $\begin{array}{l}\text { Salinity } \\
(\mathrm{MPa})\end{array}$ & $\begin{array}{l}\text { Homoge } \\
\text { suspensi }\end{array}$ & $\begin{array}{l}1 \text { biomass } \\
\mathrm{ml} \text { solvent }\end{array}$ & & \\
\hline \multirow{7}{*}{$\begin{array}{l}\overline{0} \\
\dot{\Xi}\end{array}$} & \multicolumn{4}{|c|}{$84 \pm 0.023$} \\
\hline & \multirow[t]{3}{*}{$\begin{array}{l}\dot{1} \\
\dot{5}\end{array}$} & 0.04 & $74 \pm 0.027$ & $64 \pm 0.031$ \\
\hline & & 0.08 & $90^{1} \pm 0.222$ & $70 \pm 0.285$ \\
\hline & & 0.16 & $66 \pm 0.121$ & $52 \pm 0.115$ \\
\hline & \multirow{3}{*}{ 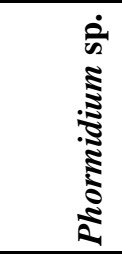 } & 0.005 & $64 \pm 0.031$ & $58 \pm 0.034$ \\
\hline & & 0.01 & $79 \pm 0.063$ & $75 \pm 0.026$ \\
\hline & & 0.02 & $56 \pm 0.053$ & $56 \pm 0.035$ \\
\hline \multirow{7}{*}{ ְֶ. } & \multicolumn{4}{|c|}{$73 \pm 0.041$} \\
\hline & \multirow{3}{*}{ 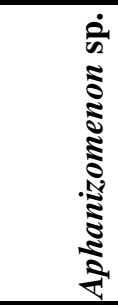 } & 0.04 & $66 \pm 0.030$ & $70 \pm 0.014$ \\
\hline & & 0.08 & $84 \pm 0.047$ & $74 \pm 0.040$ \\
\hline & & 0.16 & $54 \pm 0.166$ & $20 \pm 0.100$ \\
\hline & \multirow{3}{*}{ 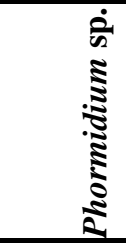 } & 0.005 & $58 \pm 0.017$ & $56 \pm 0.107$ \\
\hline & & 0.01 & $82 \pm 0.048$ & $80 \pm 0.050$ \\
\hline & & 0.02 & $56 \pm 0.035$ & $76 \pm 0.026$ \\
\hline \multicolumn{3}{|c|}{ L.S.D at $5 \%$} & 2 & 3 \\
\hline \multicolumn{3}{|c|}{ L.S.D at $1 \%$} & 3 & 4 \\
\hline
\end{tabular}

1 
Table 3: Effect of different concentrations of two cyanobacterial extracts of Phormidium sp. on the germination of cowpea seeds in the control and salinityinduced stress conditions (3-d-old).

\begin{tabular}{|c|c|c|c|}
\hline \multicolumn{2}{|r|}{ Treatments } & \multirow{2}{*}{$\begin{array}{l}\text { Germination\% } \\
\text { of aqueous extract } \\
\text { (Solvent: water) }\end{array}$} & \multirow{2}{*}{$\begin{array}{c}\text { Germination\% } \\
\text { of organic extract } \\
\text { (Solvent: chloroform } \\
\text { methnol: water) }\end{array}$} \\
\hline $\begin{array}{l}\text { Salinity } \\
\text { (MPa) }\end{array}$ & $\begin{array}{l}\text { Homogenised algal biomass } \\
\text { suspension in } 100 \mathrm{ml} \text { solvent }\end{array}$ & & \\
\hline \multirow{4}{*}{ 㝘o } & 0.0 & \multicolumn{2}{|r|}{84} \\
\hline & 0.005 & 64 & 58 \\
\hline & 0.01 & 79 & 75 \\
\hline & 0.02 & 56 & 56 \\
\hline \multirow{4}{*}{\begin{tabular}{l}
\multirow{1}{*}{} \\
\end{tabular}} & 0.0 & \multicolumn{2}{|r|}{73} \\
\hline & 0.005 & 58 & 56 \\
\hline & 0.01 & $82^{1}$ & 80 \\
\hline & 0.02 & 56 & 76 \\
\hline \multicolumn{2}{|r|}{ L.S.D at $5 \%$} & 4 & 5.66 \\
\hline \multicolumn{2}{|r|}{ L.S.D at $1 \%$} & 4 & 4 \\
\hline
\end{tabular}

0.08\% concentration of Aphanizomenon sp. algal suspension gave highest germination percentage as compared to control and salinity. It is noteworthy that none of the concentrations of algal suspension whether in aqueous or organic extract enhanced germination percentage as compared to control.

The aqueous extract of Phormidium and all treatment of organic extract decreased the content of total soluble proteins when compared with control. Nonetheless, under salinity stress all treatment of two extracts increased the total soluble protein content except with aqueous treatment of Phormidium which decreased the value from 6.46 to 4.84. Organic extract for cyanobacterial Aphanizomenon and Phormidium or their combination showed signifcant increase in the content of totat soluble sugars when compared with aqueous extract in unstressed seeds. In response to salinity stress cowpea seeds showed a significant reduction in their total soluble sugars content (Table 3). However, these values significantly increased by all treatments of two different cyanobacterial extracts, 
but the most effective treatment was recorded by the combination between Aphanizomenon and Phormidium with aqueous and organic extracts. There was a significant increase in the amount of the amino acid proline in the seeds of cowpea in response to of salinity stress. The minimum values were obtained with the sowing of seeds with aqueous extract of cyanobacterial Aphanizomenon that reduced proline content under stressed and unstressed conditions.

Table 3: Effect of different cyanobacterial extracts (Aphanizomenon sp. and Phormidium sp.) on germination percentage, soluble sugars, and proteins ( $\mathrm{mg} \mathrm{g}$ $\left.{ }^{1} \mathrm{~d} . \mathrm{wt}\right)$ content and proline, nucleic acids ( $\left.\mathrm{mg} \mathrm{g}^{-1} \mathrm{f} . \mathrm{m}\right)$ content of cowpea seeds in the control and salinity-induced stress conditions during germination (3-d-old).

\begin{tabular}{|c|c|c|c|c|c|c|c|c|}
\hline \multicolumn{3}{|c|}{ Treatments } & \multirow[b]{2}{*}{$\begin{array}{c}\text { Germination } \\
\%\end{array}$} & \multirow[b]{2}{*}{$\begin{array}{c}\text { Total soluble } \\
\text { protein }\end{array}$} & \multirow[b]{2}{*}{$\begin{array}{l}\text { Total soluble } \\
\text { carbohydrate }\end{array}$} & \multirow[b]{2}{*}{ proline } & \multirow[b]{2}{*}{ DNA } & \multirow[b]{2}{*}{ RNA } \\
\hline \multicolumn{2}{|c|}{$\begin{array}{l}\text { Salinity } \\
(\mathrm{MPa})\end{array}$} & $\begin{array}{c}\text { Algal } \\
\text { treatments }\end{array}$ & & & & & & \\
\hline \multirow{7}{*}{${ }^{\overrightarrow{0}}$} & \multirow{4}{*}{$\begin{array}{c}\text { Aqueous } \\
\text { extract }^{3}\end{array}$} & 0.0 & 84 & 9.61 & 13.66 & 0.422 & 4.54 & 9.95 \\
\hline & & $\mathrm{A}^{\mathrm{T}}$ & 90 & 11.65 & 15.23 & 0.357 & 7.32 & 11.36 \\
\hline & & $\mathrm{P}^{2}$ & 79 & 6.98 & 7.55 & 0.380 & 4.07 & 9.00 \\
\hline & & $\mathrm{A}+\mathrm{P}$ & 80 & 11.28 & 12.35 & 0.407 & 6.93 & 7.00 \\
\hline & \multirow{3}{*}{$\begin{array}{l}\text { Organic } \\
\text { extract }\end{array}$} & $\mathrm{A}$ & 70 & 6.12 & 14.36 & 0.480 & 1.85 & 8.82 \\
\hline & & $\mathrm{P}$ & 75 & 7.48 & 15.12 & 0.450 & 1.05 & 9.01 \\
\hline & & $\mathrm{A}+\mathrm{P}$ & 61 & 7.99 & 15.18 & 0.265 & 6.85 & 6.61 \\
\hline \multirow{7}{*}{$\mathfrak{i}_{1}^{1}$} & \multirow{4}{*}{$\begin{array}{c}\text { Aqueous } \\
\text { extract }\end{array}$} & 0.0 & 73 & 6.46 & 5.97 & 0.480 & 2.67 & 9.17 \\
\hline & & A & 84 & 17.91 & 6.94 & 0.450 & 8.09 & 10.87 \\
\hline & & $\mathrm{P}$ & 82 & 4.84 & 5.99 & 0.265 & 3.26 & 9.39 \\
\hline & & $\mathrm{A}+\mathrm{P}$ & 82 & 31.52 & 14.33 & 0.512 & 7.16 & 6.83 \\
\hline & \multirow{3}{*}{$\begin{array}{l}\text { Organic } \\
\text { extract }\end{array}$} & $\mathrm{A}$ & 74 & 7.14 & 6.93 & 0.297 & 4.27 & 9.51 \\
\hline & & $\mathrm{P}$ & 80 & 7.31 & 10.97 & 0.432 & 3.13 & 10.08 \\
\hline & & $\mathrm{A}+\mathrm{P}$ & 66 & 9.87 & 13.17 & 0.345 & 6.16 & 6.87 \\
\hline \multicolumn{3}{|c|}{ L.S.D at $5 \%$} & 5 & 0.032 & 0.456 & 0.202 & 0.062 & 0.027 \\
\hline \multicolumn{3}{|c|}{ L.S.D at $1 \%$} & 6.67 & 0.043 & 0.611 & 0.278 & 0.080 & 0.040 \\
\hline
\end{tabular}

A stands for Aphanizomenon sp.

${ }^{2} \mathrm{P}$ stands for Phormidium sp.

Aqueous extract for Aphanizomenon sp. gave highest values in all parameters measured and was used as the base for subsequent pot experiments.

It was observed that organic extract for cyanobacterial Aphanizomenon and Phormidium showed significant increase in the proline content when compared with aqueous extract in unstressed seeds (Table 3). DNA content was negatively affected by salinity stress, but there was improvement in DNA content by aqueous extract of cyanobacterial Aphanizomenon and the combination with Phormidium 
treatments under stressed and unstressed conditions. However, the organic extract for cyanobacterial Aphanizomenon and Phormidium showed significant decrease in the DNA content when compared with control value but these values were increased under salinity stress (Table 3). RNA content was significantly reduced by salinity stress, in a similar trend to that of DNA, and it tended to increase with the treatment by aqueous extract of cyanobacterial Aphanizomenon under stressed and unstressed conditions, but the treatments of aqueous and organic extracts of cyanobacterial Phormidium and their combination with Aphanizomenon decreased RNA content when compared with control value (Table 3 ).

Data in (Table 4) indicate that the activity of protease enzyme in the germinating seeds of cowpea, decreased with all treatments of aqueous or organic extracts that the lowest value was observed with the treatment of organic extract of cyanobacterial Phormidium, but the treatments with aqueous extract of cyanobacterial Aphanizomenon and Phormidium or organic extract of cyanobacterial Aphanizomenon stimulated the activity of protease enzyme under salinity stress conditions. The treatments of cowpea seeds with aqueous or organic extracts of different cyanobacterial species increased the activity of ribonuclease enzyme in stressed and unstressed conditions. Interestingly, the levels of activity of ribonuclease enzyme at organic extract of different species were always lower than the values of aqueous extract of different species in stressed and unstressed conditions. The $\beta$-amylase enzyme activity was also negatively affected by different cyanobacterial extracts except with the treatment of aqueous extract of cyanobacterial Aphanizomenon that increased the activity of $\beta$-amylase enzyme from 682.02 to 708.02 when compared with control value. However, the germinating seeds of cowpea showed a stimulatory effect in response to the different treatments of aqueous or organic extracts except with organic extract of Aphanizomenon that reduced the activity of $\beta$-amylase enzyme from 180.25 to 136.52 , under salinity stress conditions.It was observed that the activity of $\alpha$ amylase enzyme significantly decrease in response to salinity stress, but aqueous extract of Aphanizomenon and Phormidium and their combination stimulated the activity of $\alpha$-amylase enzyme, on the other hand organic extracts of different cyanobacterial species reduced the activity of $\alpha$-amylase enzyme under stressed and unstressed conditions, that the lowest value of activation was obtained with the treatment with Aphanizomenon.

Phormidium and their combinations compared with control value. Salinity stress caused an increase in the value of lipid per-oxidation but this increment tended to decrease with the treatments of aqueous extracts of Aphanizomenon and Phormidium. Finally, organic extract of different cyanobacterial species caused a significant increase in the level of lipid peroxidation under stressed and unstressed conditions. 
Table 4: Effect of different cyanobacterial extracts (Aphanizomenon $s p$. and Phormidium sp.) on the activities of some hydrolytic enzymes (units of product $\mathrm{g}^{-1}$ f.m. $\mathrm{s}^{-1}$ ) of cowpea seeds in the control and salinity-induced stress conditions during germination (3-d-old).

\begin{tabular}{|c|c|c|c|c|c|c|}
\hline \multicolumn{3}{|c|}{ Treatments } & \multirow{2}{*}{ protease $^{1}$} & \multirow{2}{*}{ Ribonuclease $^{2}$} & \multirow{2}{*}{$\beta$-amylase ${ }^{3}$} & \multirow{2}{*}{$\alpha$-amylase } \\
\hline & $\begin{array}{l}\text { inity } \\
\mathrm{Pa})\end{array}$ & $\begin{array}{c}\text { Algal } \\
\text { treatments }\end{array}$ & & & & \\
\hline \multirow{7}{*}{ 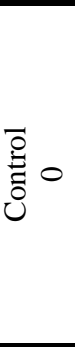 } & \multirow{4}{*}{$\begin{array}{l}\text { Aqueous } \\
\text { extract }\end{array}$} & 0.0 & 2.47 & 18.88 & 682.02 & 434.39 \\
\hline & & $\mathrm{A}$ & 1.74 & 31.86 & 708.02 & 596.92 \\
\hline & & $\mathrm{P}$ & 1.62 & 29.66 & 568.55 & 247.35 \\
\hline & & $\mathrm{A}+\mathrm{P}$ & 1.52 & 10.35 & 374.10 & 473.39 \\
\hline & \multirow{3}{*}{$\begin{array}{l}\text { Organic } \\
\text { extract }\end{array}$} & $\mathrm{A}$ & 1.00 & 23.25 & 231.08 & 127.65 \\
\hline & & $\mathrm{P}$ & 0.992 & 20.56 & 273.04 & 235.81 \\
\hline & & $\mathrm{A}+\mathrm{P}$ & 1.41 & 13.67 & 285.45 & 265.95 \\
\hline \multirow{7}{*}{ No } & \multirow{4}{*}{$\begin{array}{l}\text { Aqueous } \\
\text { extract }\end{array}$} & 0.0 & 1.28 & 8.17 & 180.25 & 146.57 \\
\hline & & $\mathrm{A}$ & 1.65 & 38.15 & 544.91 & 376.47 \\
\hline & & $\mathrm{P}$ & 2.27 & 22.19 & 509.45 & 374.70 \\
\hline & & $\mathrm{A}+\mathrm{P}$ & 0.998 & 10.43 & 420.20 & 328.60 \\
\hline & \multirow{3}{*}{$\begin{array}{l}\text { Organic } \\
\text { extract }\end{array}$} & $\mathrm{A}$ & 1.52 & 12.93 & 136.52 & 124.11 \\
\hline & & $\mathrm{P}$ & 1.25 & 12.04 & 280.13 & 200.35 \\
\hline & & $\mathrm{A}+\mathrm{P}$ & 0.310 & 10.87 & 277.77 & 161.34 \\
\hline \multicolumn{3}{|c|}{ L.S.D at $5 \%$} & 0.043 & 0.408 & 0.121 & 0.084 \\
\hline \multicolumn{3}{|c|}{ L.S.D at $1 \%$} & 0.057 & 0.546 & 0.160 & 0.113 \\
\hline
\end{tabular}

${ }^{1}$ The substrate was albumin.

${ }^{2}$ The substrate was RNA

3 The substrate was starch

${ }^{4}$ The substrate was starch

In general, it was observed that the electrolyte leakage from root segments of cowpea increased with time at all treatments of aqueous or organic extracts and increased by salinity stress, as compared with control value but there is significant decrease in the value of the electrolyte leakage from roots of treated seeds with aqueous extract of Aphanizomenon and Phormidium under salinity stress. However roots of seeds treated with organic extract of cyanobacterial Aphanizomenon, Phormidium and their combination and grown under salinity stress had highest values of electrical conductivity (Table 5). Lipid peroxidation was measured as the thiobarbituric acid reactive substances (TBARS), and expressed as the percentage of increase or decrease from the controls (Table 5). 
Lipid peroxidation has been found to be decease in response to different treatments of aqueous extracts of Aphanizomenon, Phormidium and their combinations compared with control value. Salinity stress caused an increase in the value of lipid per-oxidation but this increment tended to decrease with the treatments of aqueous extracts of Aphanizomenon and Phormidium. Finally, organic extract of different cyanobacterial species caused a significant increase in the level of lipid peroxidation under stressed and unstressed conditions.

Table 5: Effect of different cyanobacterial extracts (Aphanizomenon sp. and Phormidium sp.) on the electrolyte leakage after 10, 20 and 30 min and after boiling of root segments, and the relative permeability of the root membranes and changes in lipid peroxidation (thiobarbituric acid reactive substances, TBARS) was expressed as the percentage of increase or decrease from the control values of cowpea seeds in the control and salinity-induced stress conditions during germination (3-d-old)

\begin{tabular}{|c|c|c|c|c|c|c|c|c|}
\hline \multicolumn{3}{|c|}{ Treatments } & \multicolumn{4}{|c|}{ Electrolyte leakage at different time periods } & \multirow{2}{*}{$\begin{array}{l}\% \text { of the } \\
\text { relative } \\
\text { permeability }\end{array}$} & \multirow{2}{*}{$\begin{array}{l}\% \text { of changes } \\
\text { of relative } \\
\text { Lipid } \\
\text { peroxidation }\end{array}$} \\
\hline & $\begin{array}{l}\text { Salinity } \\
\text { (MPa) }\end{array}$ & $\begin{array}{c}\text { Algal } \\
\text { treatments }\end{array}$ & $10 \min$ & $20 \min$ & $30 \mathrm{~min}$ & $\begin{array}{c}\text { After } \\
\text { boiling }\end{array}$ & & \\
\hline \multirow{7}{*}{ 总o } & \multirow{4}{*}{$\begin{array}{c}\text { Aqueous } \\
\text { extract }\end{array}$} & 0.0 & 8 & 9 & 12 & 111 & 10.81 & 139.84 \\
\hline & & $\mathrm{A}$ & 9 & 11 & 13 & 112 & 11.60 & 34.45 \\
\hline & & $\mathrm{P}$ & 8 & 9 & 17 & 144 & 11.80 & 165.03 \\
\hline & & $\mathrm{A}+\mathrm{P}$ & 12 & 19 & 29 & 236 & 12.28 & 45.94 \\
\hline & \multirow{3}{*}{$\begin{array}{c}\text { Organic } \\
\text { extract }\end{array}$} & $\mathrm{A}$ & 14 & 25 & 31 & 282 & 10.99 & 316.39 \\
\hline & & $\mathrm{P}$ & 15 & 19 & 23 & 210 & 10.95 & 258.16 \\
\hline & & $\mathrm{A}+\mathrm{P}$ & 20 & 39 & 47 & 266 & 17.66 & 445.94 \\
\hline \multirow{7}{*}{$\stackrel{N}{i}$} & \multirow{4}{*}{$\begin{array}{c}\text { Aqueous } \\
\text { extract }\end{array}$} & 0.0 & 15 & 20 & 22 & 180 & 12.22 & 316.88 \\
\hline & & $\mathrm{A}$ & 11 & 14 & 19 & 181 & 10.49 & 122.32 \\
\hline & & $\mathrm{P}$ & 10 & 19 & 20 & 178 & 11.23 & 218.82 \\
\hline & & $\mathrm{A}+\mathrm{P}$ & 17 & 21 & 24 & 156 & 15.38 & 525.71 \\
\hline & \multirow{3}{*}{$\begin{array}{c}\text { Organic } \\
\text { extract }\end{array}$} & $\mathrm{A}$ & 28 & 40 & 48 & 255 & 18.82 & 513.63 \\
\hline & & $\mathrm{P}$ & 18 & 37 & 46 & 266 & 17.29 & 333.28 \\
\hline & & $\mathrm{A}+\mathrm{P}$ & 30 & 41 & 49 & 255 & 19.21 & 546.62 \\
\hline \multicolumn{3}{|c|}{ L.S.D at $5 \%$} & & & & & 0.056 & 0.011 \\
\hline \multicolumn{3}{|c|}{ L.S.D at $1 \%$} & & & & & 0.076 & 0.011 \\
\hline
\end{tabular}




\section{Discussion}

Gadwal and Naik (2014) stated that salinity stress can affect seed germination through reduction of water uptake leading to moisture stress (osmotic effect), by ion toxicity and/or ionic imbalance, or by the accumulation of $\mathrm{Na}^{+}$and $\mathrm{Cl}^{-}$ions and inhibition of the uptake of several essential nutrients such as $\mathrm{K}^{+}$ causing nutritional imbalance in the plants or accumulation of these factors. Palaniappan et al. (2010) evaluated that the various concentrations of the aqueous extract obtained from a 30 day old immobilized culture of Phormidium and its aqueous extract significantly improved the germination of cowpea seeds under in vitro conditions that the extracellular organic bioactive compounds produced by the cyanobacterium are proposed to play a positive role in plant growth.

There was a notable decrease in the content of the total soluble sugars and proteins during seed germination under salinity stress, which might be due to a partial inhibition of the hydrolytic activity of amylase and protease enzymes under low water potential conditions. Treatment with different cyanobacterial species especially with aqueous extract of cyanobacterial Aphanizomenon flos-aquae led to a general increase in the cellular content of total soluble sugars and total soluble proteins. The improvement of the growth and nitrogen contents in response of application of cyanobacteria could be attributed to the nitrogen as well as nitrate reductase activities (Adam 1999). Zeid (2009) suggested that the decrease in nucleic acids content in bean occurred concurrently with the increase in RNase activity caused by the elevation in salinity level which might be involved in inhibiting nucleic acids biosynthesis and/or stimulating their degradation. Nevertheless, there was a pronounced improvement in DNA and RNA contents by the influence of cyanobacterial extracts, particularly with that of Aphanizomenon flos-aquae in both salt-stressed and unstressed plants. Shehata and El-Khawas (2003) concluded that the nucleic acids (DNA and RNA) contents were much higher in seed yield obtained from plants treated biofertilizers. This may be due to the active synthesis of nucleic acids simultaneously occurring with decreasing the hydrolytic and oxidative enzyme activities. Proline content increased in salt-stressed germinating seeds. However, the treatments with cyanobacteria significantly reduced this increment. This response may be attributed to an improvement of the water status of the stressed plants (El-Gamal et al., 2008). Proline has several functions during stress: osmoprotection (Kishor $\boldsymbol{e t}$ al., 2005), free radical scavenging activity as well as antioxidant potential (Sharma and Dietz, 2006). It may also serve in regulating cytosolic acidity (Sivakumar et al., 2000). Hoque et al. (2008) showed that proline improves salt tolerance in Nicotiana plants by increasing the activity of enzymes involved in the antioxidant defense system. During seed germination, the hydrolytic activity of $\alpha$ - and $\beta$-amylases, invertase, protease and ribonuclease

Egyptian J. of Phycol. Vol. 15, 2014 
decreased by the influence of salt-induced stress. This might be ascribed to the osmotic stress which decreased the amount of the available water required for hydrolysis of the reserves and translocation of the hydrolyzates to the embryo axis. Therefore, the inhibition of the hydrolytic activities during germination leads to decreasing both germination percentage and germination rate coupled with decrease in alpha-amylase activity in germinating seeds (Chen and Zhao, 1996). Hydrolysis of the grain reserve materials of starch and protein enables the embryo axes to utilize the hydrolyzates for early growth. Therefore, the delaying in germination under salinity stress might be attributed to the partial inhibition in amylase activity (Zeid, 2011). The treatments of cowpea seeds with aqueous or organic extracts of different cyanobacterial species increased the activity of all studied enzymes especially with aqueous extract of cyanobacterial Aphanizomenon sp. High salinity levels caused a considerable reduction in water permeability in the cortex (Azaizeh et al., 1992) thereby reducing the osmotic water permeability by as much as fivefold. Changes in the osmotic water permeability were reflected in changes in root hydraulic conductivity due to the fact that most of the water was flowing around cells (Azaizeh and Steudle, 1991). Lipid peroxidation induced by free radicals, is associated with membrane deterioration (Khan and Panda, 2008). The reducing effect of different cyanobacterial species on the lipid peroxidation and relative permeability of plasma membranes of cowpea roots of germinating seeds was noticed under salinity stress. Aqueous Aphanizomenon flos-aquae cyanobacterial extract was the most effective treatment. This positive response indicates an increased tolerance to salinity stress and more stability in plasma membranes. Similarly, Abd El Baky et al. (2014) observed a significant decrease in lipid peroxide products (TBARs) and sodium ions concentrations in wheat plants (Triticum aestivum L.) irrigated with either 10 or $20 \%$ of Seawater (SW) were treated with aqueous extracts of green microalgae.

\section{Conclusion}

The aqueous algal extracts alleviated the harmful effect of salinity on seed germination. This can be used as a farming strategy on a mass scale as a costeffective, environment-friendly policy to ameliorate the hazardous effect of salinity on plants especially during the critical period of seed germination where salinity can drastically inhibit germination causing massive economic loss.

\section{References}

Abd El Baky, H. H.; Hussein, M. M. and El-Baroty, G. S. (2014). Induces of antioxidant compounds and salt tolerance in wheat plant irrigated with 
seawater as response to application of microalgae spray. American Journal of Agricultural and Biological Sciences 9 (2): 127-137.

Abd El-Baky, H. H.; Hussein, M. M. and El-Baroty, G. S. (2008). Algal extracts improve antioxidant defense abilities and salt tolerance of wheat plant irrigated with sea water. African Journal of Biochemistry Research 2 (7):151 - 164.

Adam M. S. (1999). The promotive effect of the cyanobacterium Nostoc muscorum on growth of some crop plants. Acta Microbiology Polo 48:163-71.

Azaizeh, H. and Steudle, E. (1991). Effects of salinity on water transport of excised maize (Z. mays L.) roots. Plant Physiol 97:1136-45.

Azaizeh, H.; Gunse, B. and Steudle, E. (1992). Effects of $\mathrm{NaCl}$ and $\mathrm{CaCl} 2$ on water transport across root cells of maize (Zea mays L.) seedlings. Plant Physiol 99:886-894.

Baset, M. M. A. and Shamsuddin, Z. H. (2010). Rhizobium as a crop enhancer and biofertilizer for increased cereal production. African Journal of Biotechnology 9(37): 6001-6009.

Bates, L. S.; Waldren, R. P. and Teare, I. D. (1973). Rapid determination of free proline for water stress studies Plant and Soil. 39: 205-207.

Bergmeyer, H. U. (ed) (1974). Methods of Enzymatic Analysis. Verlag Chemic, Weinheim, Academic Press, New York London

Bernheim, F.; Bernheim, M. L. C. and Wilbur, K. M. (1948). The reaction between thiobarbituric acid and the oxidation product of certain lipids.J BiolChem 174: 254-264.

Chen, X. L. and Zhao, K. F. (1996). Effect of $\mathrm{NaCl}$ stress on germination of maize seeds and the alleviation of exogenous $\mathrm{Ca}^{2+}$. Acta Agriculturae Boreali Sinica 11(4): 89-92.

Clyde, W.; Liu, X.; Lesch, S. M. and Suarez, D. L. (2006). Growth response of major USA cowpea cultivars II Effect of salinity on leaf gas exchange. Plant Science 170:1095-1101.

Dische, Z. and Scwartz, Z. (1973). Thin Layer Chromatography. Micochin Acta, 2, 13 Cited by: E Stahal (ed) $2^{\text {nd }}$ Spriger Verlage Berlin

Dkhil, B. B. and Denden, M. (2010). Salt stress induced changes in germination, sugars, starch and enzyme of carbohydrate metabolism in Abelmoschus esculentus L. (Moench) seeds African Journal of Agricultural Research 5(12):1412-1418.

El-Gamal, D.; Ghanem, A. E. N.; El-Ayouty, E. Y. and El-Belely, E. F. (2008). Differential responses of Anabaena Variabilis and Nostoc Linckia to salt stress and their role in improvement the growth conditions 
of some salt stressed plant seedlings. International Conference for Enhancing Scientific Research: New Horizons Tanta Conference1-10

Feuillade, J. (1994). The cyanobacterium (blue green alga). Oscillatoria rubescence DC Archives of Hydrobiology 42: 77-93.

Gadwal, R. and Naik, G. R. (2014). A comparative study on the effect of salt stress on seed germination and early seedling growth of two Hibiscus species. Journal of Agriculture and Veterinary Science.7:(3) 90-96.

Hoque, M. A.; Okuma, E.; Nakamara, Y.; Shimoishi, Y. and Murata, Y. (2008). Proline and glycinebetaine enhance antioxidant defense and methylglyoxal detoxification systems and reduce NaClinduced damage in cultured tobacco cells. J Plant Physiol 165:813-824.

Hu, Y. C.; Fricke, W. and Schmidhalter, U. (2005). Salinity the growth of nonhalophytic grass leaves: the role of mineral nutrient distribution. Chair of Plant Nutrition Functional Plant Biology 32(11): 973-985.

Kay, R. A. and Barton, L. L. (1991). Microalgae as food and supplement. Critical Reviews in Food Science and Nutrition 30 (6): 555-573.

Khan, M. H. and Panda, S. K. (2008). Alterations in root lipid peroxidation and antioxidative responses in two rice cultivars under $\mathrm{NaCl}$-salinity stress. Acta Physiol Plant 30:91-89.

Kishor, P. B. K.; Sangam, S.; Amrutha, R. N.; Laxmi, P. S.; Naidu, K. R. and Rao, K. S. (2005). Regulation of proline biosynthesis, degradation, uptake and transport in higher plants: its implications in plant growth and abiotic stress tolerance. Curr Sci (88): 424-438.

Kumar, G. and Sahoo, D. (2011). Effect of seaweed liquid extract on growth and yield of Triticum aestivum var. Pusa Gold. J Appl Phycol 23: 251-255.

Marmur, J. (1961). A procedure for the isolation of deoxyribonucleic acid from microorganisms. Bot J 208-18.

Munns, R. (2002). Comparative physiology of salt and water stress. Plant Cell and Environment 25: 239-250.

Oktem, H. A.; Eyidogan, F.; Selcuk, F.; Silva, J. A. T. D. and Yucel, M. (2006). Osmotic stress tolerance in plants: transgenic strategies. Floriculture Ornamental and Plant Biotechnology 194-208.

Palaniappan, P.; Malliga, P.; Manian, S.; Madhaiyan, S. S. M. and Sa, T. (2010). Plant growth promontory effect on Cow pea (Vigna unguiculata L) using coir pith aqueous extract formulation of cyanobacterium Phormidium. American-Eurasian J Agric and EnvironSci 89(2): 178-184.

Sharma, S. S. and Dietz, K. J. (2006). The significance of amino acids and amino acid-derived molecules in plant responses and adaptation to heavy metal stress. J Exp Bot. 57:711-726.

Egyptian J. of Phycol. Vol. 15, $2014 \quad$ - 74 - 
Shehata, M. M. and El-Khawas, S. A. (2003). Effect of two biofertilizers on growth parameters, yield characters, nitrogenous components, nucleic acids content, minerals, oil content, protein profiles and DNA banding pattern of sunflower ( Helianthus annus L cv Vedock) yield. Pakistan Journal of Biological Sciences 6(14):1257:1268.

Sheoran, I. S. (1980). Changs in amylase during germination and early seedling growth of mung bean (Vigna radiate 1). Eilczek under different salts Indian J Plant Phsiol 23: 169-173.

Siam, H. (2008). Increasing the efficiency of utilization of nitrogenous fertilizers through addition of Banana compost on growth, yield and nutrients of cowpea plants. Egypt J of Appl Sci 23(7): 54-6.

Sivakumar, P., Sharmila, P. and Saradhi, P. P. (2000). Proline alleviates saltstress induced enhancement in Rubisco oxygenase activity. Biochem Biophys Res Commun 279:512-515.

Snedecor, G. W. and Cochran, W. G. (1980). Statistical Methods. $6^{\text {th }}$ Ed. Iowa State University Press Ames

Thakur, M. and Sharma, A. D. (2005). Salt stress and phytohormone (ABA) induced changes in germination, sugars and enzymes of carbohydrate metabolism in Sorghum bicolor (L) Moench seeds. JAgric Soc Sci 1: 8993.

Umbriet, W. W.; Burris, R. H.; Stauffer, J. F.; Cohen, P. P.; Johanse, W. J.; Lee, P. G. A.; Potter, V. R. and Schneider, W. C. (1959). Monometric technique, a manual descripton method, applicable to study of desiring metabolism. P 239 Burgess Publishing Company (cf Razak AA 1979)

Venkataraman, G. S. (1981). Blue-green algae for rice production-a manual for its promotion. FAO Soils Bull, 46: 1-52.

Zayed, M. A. and Zeid, I. M. (1998). Effect of water and salt stresses on growth, chlorophyll, mineral ions and organic solutes contents and enzymes activity in mungbean seedlings. Biol Plant 40: 351-356.

Zeid, I. M. (2004) Responses of bean (Phaseolus vulgaris) to exogenous putrescine treatment under salinity stress. Pakistan J Biol Sci 7(2): 219225.

Zeid, I. M. (2009). Effect of arginine and urea on polyamines content and growth of bean under salinity stress. Acta Physiol Plant, 31: 65-70.

Zeid, I. M. (2011). Allevation of seawater stress during germination and early growth of barley. International Journal of Agriculture: Research and Review, 1 (2): 59-67.

Zwiazek, J. J. and Blake, T. J. (1991). Early detection of membrane injury in black spruce (Picea mariana). can J for Res 21: 401-404.

Egyptian J. of Phycol. Vol. 15, 2014 


\title{
مكافحة التأثير المثبط للإجهاد الناتج عن الملوحة على إنبات اللوبيا باستخدام المستخلصات السياتوباكتيرية التماتية
}

\author{
ابراهيم محمد زيد، صفيه محمد غازى، نرمين عادل السمرى، أميرة محمد عبد الستار

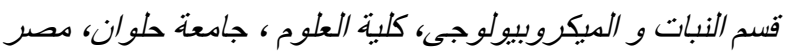

تمت دراسة استجابة بذور اللوبيا التي نمت نحت ظروف الإجهاد الناتجة عن الملوحة لمختلف

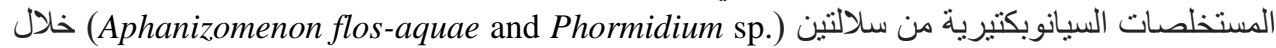
إنبات البذور. و أظهرت النتائج أن المستخلص المنائي كان أكثر تحفيز للإنبات من المستخلص العضوب العنوي

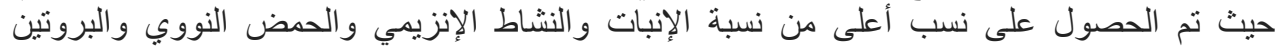

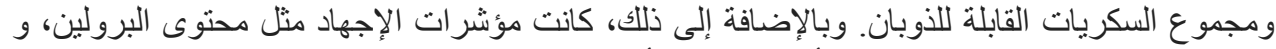

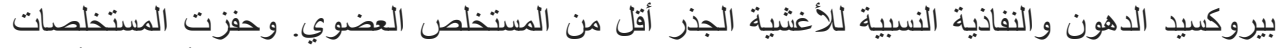

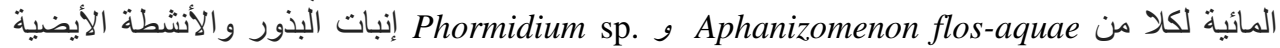

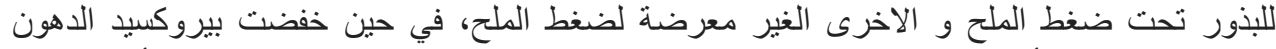

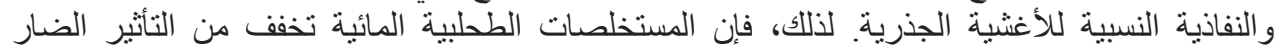

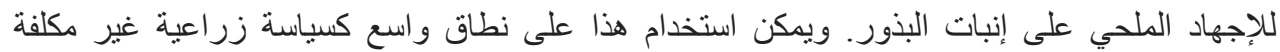

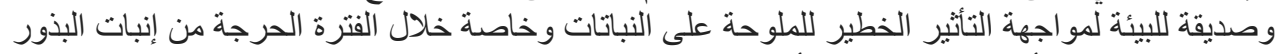
حيث يمكن للملوحة أن تمنعها إما جزئيا أو كليا. 